\title{
混合モード荷重下における延性破壊機構の研究*
}

菊 池 正 紀*1, 山王丸 将吾*2

\section{Study on the Ductile Fracture under Mixed Mode Loading Condition}

\author{
Masanori KIKUCHI ${ }^{* 3}$ and Shougo SANNOUMARU \\ *3 Department of Mechanical Engineering, Tokyo University of Science, \\ 2641 Yamazaki, Noda-shi, Chiba, 278-8510 Japan
}

\begin{abstract}
Three point bend specimen is used for ductile fracture tests with different mixed mode ratio, $\mathrm{K}_{\mathrm{II}} / \mathrm{K}_{\mathrm{I}}$. The crack growth direction in mid-plane of the specimen changes largely with the change of $\mathrm{K}_{\mathrm{II}} / \mathrm{K}_{\mathrm{I}}$ value. Detailed observation of fracture surface is conducted, and it is shown that the average void diameter becomes smaller as $K_{I I} / K_{I}$ becomes lager. Numerical simulation is also carried out using Gurson's yield function. By in troducing stress ${ }^{-}$controlled void nucleation model, as well as plastic-strain-controlled nucleation model, it is shown that crack growth directions at mid-plane and free surface are estimated well and results agree with experimental observations qualitatively. Distributions of stress triaxiality and plastic strain are also evaluated and their effects on dimple fracture process are discussed.
\end{abstract}

Key Words: Dimple Fracture, Mixed-Mode, Shear-Lip Fracture, Three-Point Bend Specimen, Void, FEM Analysis, Gurson Model

\section{1. 緒論}

延性材料は生産性が良いとされている塑性加工にも 適応する事ができ，また一般的に脆性材料と比べると 勒性が高い事から広い分野に渡って使用されている. 通常, ある構造物が使用されているとき構造物を構成 する各材料には荷重が負荷しているが，それが繰り返 し荷重ならば応力集中部から疲労き裂が発生する場合 がある. 過去の研究 ${ }^{(1) \sim(3)}$ から疲労き裂の多くは Mode I 荷重下で進展しやすい事が知られているため, 構造物 を長期間使用すると Mode I 荷重下で波労き裂が生ずる ことが考えられる.この状態において構造物が物体の 衝突や地震などによる予期せぬ大きな荷重を受けると, き裂先端では塑性域が大きく広がり，ついには混合モ 一ド負荷下における延性破壊に至る場合も考えられる. 混合モード負荷下における延性破壊に関する研究(4) (5) は過去にいくつかあるものの, き裂進展シミュレーシ ヨンまで考慮したものは多くない，さらに延性破壊に 関する重要な問題の一つとして挙げられるのが平面応 力領域で生ずるシャリップ破壊についてである，従来 の破壊力学では主に平面ひずみ条件を仮定していたが, 近年, 構造物の小型化や軽量化に伴い薄板構造物が増 加してきたため平面応力下での破壊，すなわちシャリ

\footnotetext{
* 原稿受付 2008 年 1 月 24 日.

*1 正員, フェロー, 東京理科大学理工学部(画 278-8510 野田市 山崎 2641).

*2 東京理科大学大学院理工学研究科.

E-mail : kik@me.noda.tus.ac.jp
}

ップ破壊領域を調べる必要性が高くなっている. シャ リップ破壊についても過去にいくつかの研究(の) ( )が見 られるが，シャリップ破壊領域も含めた 3 次元き裂進 展解析による考察は少ない，そこで本研究ではまずモ ード I とモード II の混合モード負荷下における基礎的 な延性破壊挙動として実験によりき裂進展挙動および 破面状態を調べる．次にシャリップ破壊も考虑した延 性破壊シミュレーションを行い, 混合モード比の変化 がき裂進展挙動に与える影響について力学的な視点か ら考察を行う。

\section{2. 試験片と実験方法}

高延性，高勒性材料である A533B 鋼を用いて，常温 における三点曲げ延性破壊試験を実施した。材料の化 学成分と機械的性質を表 1,2 亿示す.

Table 1 Chemical composition of A533B steel [Wt\%]

\begin{tabular}{|c|c|c|c|c|c|c|}
\hline $\mathrm{C}$ & $\mathrm{Si}$ & $\mathrm{Mn}$ & $\mathrm{P}$ & $\mathrm{S}$ & $\mathrm{Ni}$ & $\mathrm{Mo}$ \\
\hline 0.22 & 0.32 & 1.46 & 0.01 & 0.01 & 0.60 & 0.57 \\
\hline
\end{tabular}

Table 2 Mechanical property of A533B steel

\begin{tabular}{|c|c|c|c|}
\hline$E[\mathrm{GPa}]$ & $\nu$ & $\sigma_{y}[\mathrm{MPa}]$ & $R a[\%]$ \\
\hline 206 & 0.3 & 599 & 67 \\
\hline
\end{tabular}

ここでEはヤング率, $\nu$ はポアソン比， $\sigma_{y}$ は降伏応 力, $R a$ は絞り值を示す. 板厚は破壊勒性基淮 ${ }^{(8)}$ を満た すものとして $8 \mathrm{~mm}$ とした. また図 1 のように支持点 とき裂位置の距離 $X$ を変化させる事で混合モード比を 変化させた. 表 3 に本研究で用いた試験片の混合モー ド比を示す.なお図 1 中の寸法の単位は mm である. 


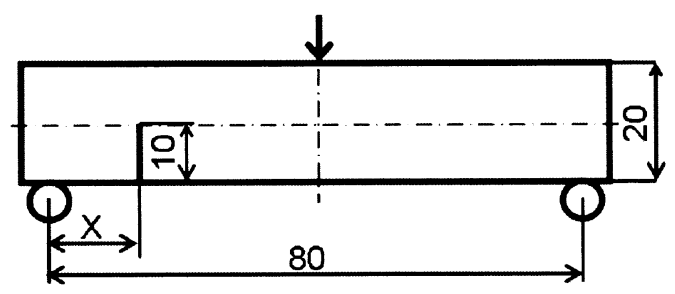

Fig. 1 Three point bend specimen

Table 3 Mixed mode ratio for the tests.

\begin{tabular}{|c|c|c|c|c|c|}
\hline $\mathrm{X}[\mathrm{mm}]$ & 40 & 24 & 20 & 16 & 12 \\
\hline $\mathrm{K}_{\mathrm{II}} / \mathrm{K}_{\mathrm{I}}$ & 0.00 & 0.130 & 0.154 & 0.189 & 0.250 \\
\hline
\end{tabular}

\section{3. 実験結果}

図 2 に破断させた試験片を示す. 図 2 (b)は図 2 (a)の 破面を拡大したものである. 図 2 から板厚内部では凹 凸の激しいディンプル破壊領域，板厚表面ではシャリ ップ破壊領域の存在が確認される. 混合モード比がき 裂進展挙動に与える基本的な性質の一つとしてき裂進 展方向一の影響が考えられるためき裂進展角度を測定 した. 図 3 は図 2(b)の破線部にそった断面高さデータ である. 図 3 の領域 A はワイヤーカット加工面, 領域 $\mathrm{B}$ は疲労予き裂面であり平坦な破面である. 領域 C は 凹凸の激しいディンプル破面である. 本研究では図 3 中の点線の様にディンプル破壊領域の破面形状を最小 二乗法により直線近似した直線の勾配からき裂進展角 度を定義した. さらに図 4 に示す様にき裂進展角度の 正負を定義した. 図 5 に混合モード比を変化させた試 験により得られた板厚中央面と板厚表面におけるき裂 進展角度を示す.

図 5 によると板厚内部ではき裂進展角度は正值をと りその值は混合モード比が上昇するにつれて大きくな っている. また板厚表面では,混合モード比がゼロのモ 一ドIのときはき裂進展角度は対称に正と負の值をと

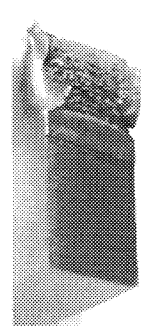

(a) Fractured specimen

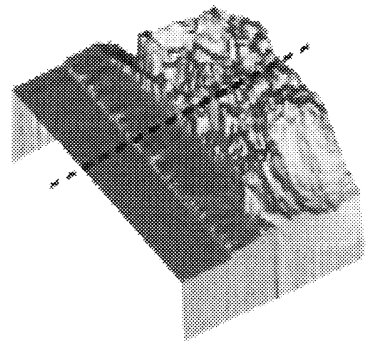

(b) Fracture surface
Fig. 2 Fractured specimen
り二方向に進展するが,混合モード状態では負の方向方向だけに進展している. 図6には板厚表面における き裂進展の様子を示す. Mode I 試験片ではき裂先端か ら左右対称にき裂が進展しているのに対して混合モー ド試験片では非対称にき裂が進展している様子が見ら れる.

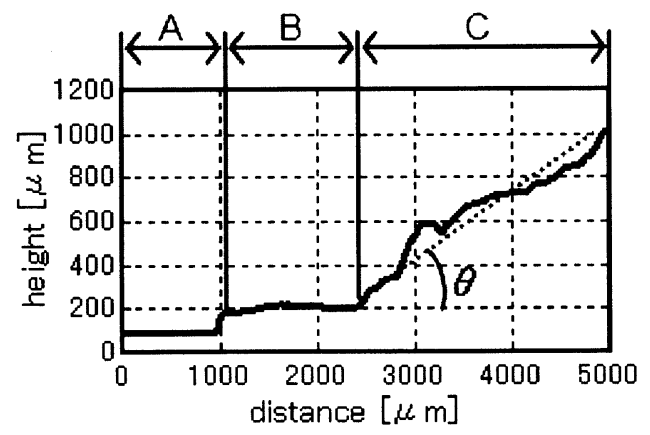

Fig. 3 Definition of crack growth direction

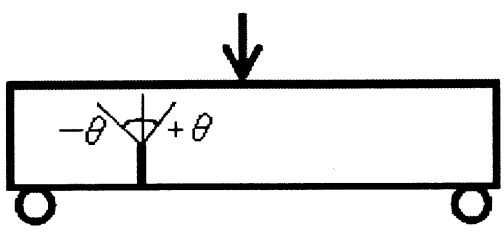

Fig.4 Definition of crack growth direction

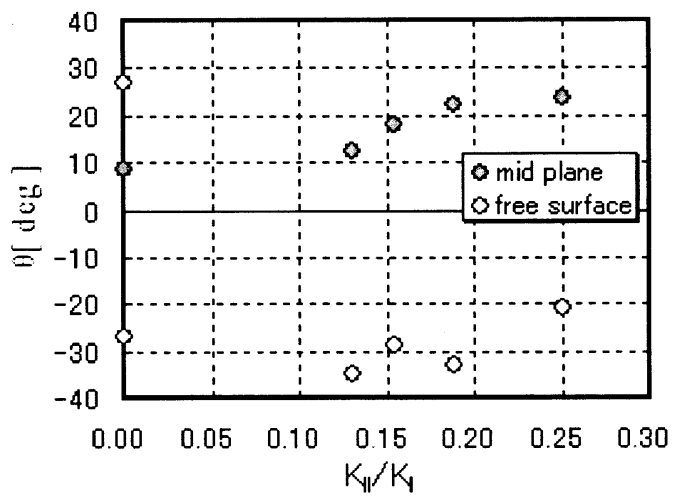

Fig. 5 Crack growth angle

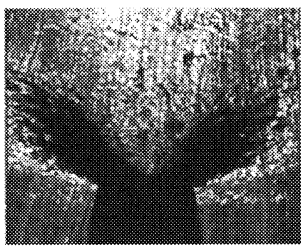

(a) Mode I $\left(\mathrm{K}_{\mathrm{II}} / \mathrm{K}_{\mathrm{I}}=0.0\right)$

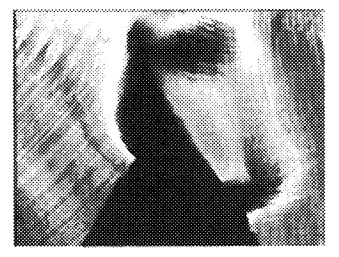

(b) $\mathrm{K}_{\mathrm{II}} / \mathrm{K}_{\mathrm{I}}=0.25$
Fig. 6 Crack growth in free surface 
次に SEM( Scanning Electron Microscope )を用いて破 面上に存在するディンプルの状態を調バた. 図 7 に Mode I 試験片の板厚内部とシャリップ破壊領域にお ける破面の写真を示寸. 図 7(a)の様に板厚内部では数十 $\mu \mathrm{m}$ 程度のディンプルが存在し，シャリップ破壊領域 でも数 $\mu \mathrm{m}$ 程度の小さいスケールではあるがディンプ ルが存在している事が確認できる，そこで混合モード 比の変化がディンプルに対してどのような影響を与え るのかを調べた. 図 8 に混合モード比の変化に対する ディンプル径の変化を板厚内部とシャリップ領域に関 して示す.グラフの各点はそれぞれの領域で 120 個の ディンプル径を測定した平均值である. 図 8 より板厚 内部では混合モード比が大きくなるにつれてディンプ ル径が小さくなる傾向が分かる．またシャリップ破壊 領域では混合モード比によらず小さなディンプルが存 在し, 混合モード比による傾向の変化も見られなかっ た. 以上からディンプルの形成が板厚表面と板厚内部 で異なっていることが推定できる.

\section{4. 有限要素法解析}

4・1 Gurson の構成方程式 破面観察結果から混 合モード比や板厚表面と内部に関わらずディンプル

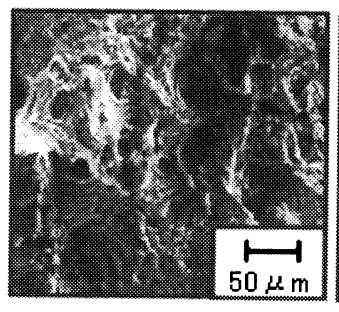

(a) Mid-plane

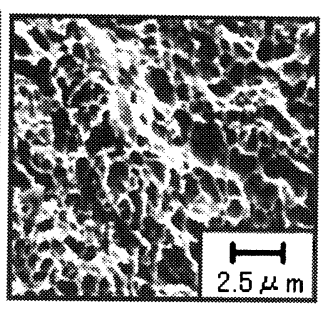

(b) Shear-lip
Fig.7 Dimples on the fracture suface

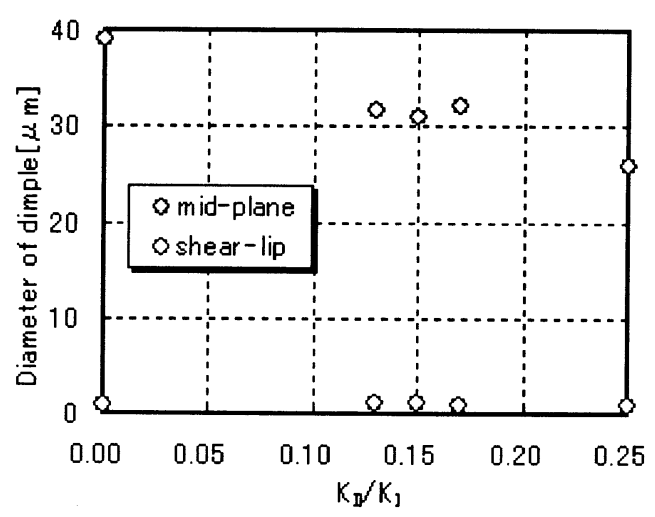

Fig.8 Diameter of dimple
が存在していた事からその破壊機構にはボイドが深く 関与していると考えられる. そこで本研究ではボイド の存在を考慮した FEM による延性破壊シミュレーシ ヨンにより混合モード負荷下におけるき裂進展挙動と 力学的環境との関連性について調べた. 構成方程式と して式（1）に示す Gursonによって提案されたボイド を考慮した降伏関数 ${ }^{(9)}$ を用いた.

$\Phi=\frac{3}{2} \frac{\sigma_{i j}^{\prime} \sigma_{i j}^{\prime}}{\bar{\sigma}_{m}^{2}}+2 f^{*} q_{1} \cosh \left(\frac{q_{2} \sigma_{k k}}{2 \bar{\sigma}_{m}}\right)-\left(1+q_{1}^{2} f^{* 2}\right)=0 \quad$ (1) ここで $\sigma_{i j}$ は偏差応力、 $\overline{\sigma_{m}}$ は相当応力であり、 $q_{1}, q_{2}$ は Tvergaard ${ }^{(10)}$ によって定められた係数で $q_{I}=1.5, q_{2}=1.0$ で ある. $f$ はボイド率と呼ばれ，材料中に占める微小空孔 の体積率である．また,ボイド率の増分は式（2）の様 にボイドの発生項と成長項に分離できる. 以下の式中 で、各記号の上に表記される・(ドット)はその量の増分 形を意味している.

$$
\dot{f}=\dot{f}_{\text {nucleation }}+\dot{f}_{\text {growth }}
$$

ボイドの発生モデルは過去の多くの研究(11)--(12) から相 当塑性ひずみ支配モデル(13) (PSCN : Plastic Strain Controlled Nucleation)により延性破壊を良く表現できる 事が知られており著者らも過去に 3 点曲げMode I モデ

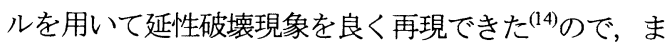
ず始めに式（3）で表される PSCN モデルを用いるこ とにした. 式（3）における $\overline{\varepsilon_{m}^{p}}$ は相当塑性ひずみ、 であり $A$ としてここでは $A=1.5 \times 10^{-1}$ の值を用いた。

$$
\dot{f}_{\text {nucleation }}=A \dot{\bar{\varepsilon}}_{m}^{p}
$$

また，ボイドの成長モデルは以下の式で表現される.

$$
\dot{f}_{\text {growth }}=(1-f) \dot{\bar{\varepsilon}}_{k k}^{p}
$$

ここで $\overline{\varepsilon_{k k}^{p}}$ はボイドを含む領域の塑性体積ひずみであ る。 これらの式により各要素のボイド率が次第に増加し, 破壊ボイド率に達したときに要素の破壊とすることで 延性破壊シミュレーションを行う事ができる. 図 9 に 混合モード比 0.25 の 2 次元解析モデルを示す. 要 素はクロストライアングル要素を用いており板厚中央 面のき裂進展について考慮する為に平面ひずみ条件と した. 図 10 は図 9 のき裂先端部を拡大したものであ る. 図 10 (a) に破壊開始前の状態, 図 10 (b)に破壊後 の状態を示す。 
図１Ｏ(b)からき裂進展角度が負となる方向に進展して いる様子が分かる.この解析結果を図 5 に示した板厚 中央面の実験結果と比較すると,き裂進展方向が反対に なっている.

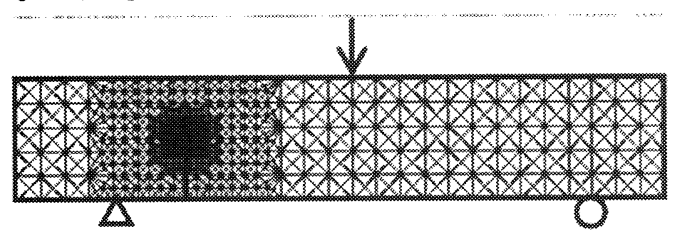

Fig.9 2-dimentional FEM model $\left(\mathrm{K}_{\mathrm{II}} / \mathrm{K}_{\mathrm{I}}=0.25\right)$

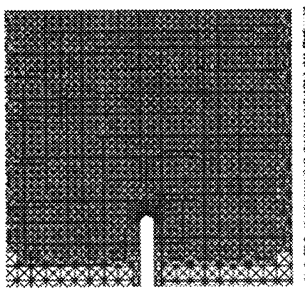

(a) Before fracture

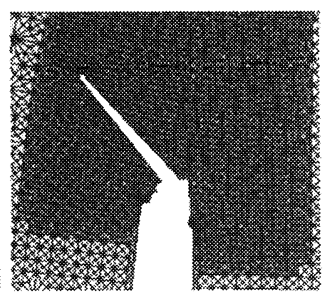

(b) After fracture
Fig. 10 Crack tip model

$4 \cdot 2$ ボイド発生モデルの検討 本研究ではこの 原因の 1 つとしてボイドの発生に関するモデル化が不 十分であると考え再検討を行った. ボイド発生モデル に関しては式（3）に示したように一般的に広く使わ れている PSCN があるが，一方，母材中の介在物の界 面に垂直に働く応力がある臨界值に達寸るとボイドが 発生するという考えによる応力支配（SCN：Stress Controlled Nucleation) モデル(15)がある. SCN モデルに よるボイドの発生項を式（5）に示す.

$$
\dot{f}_{\text {nucleation }}=B\left(\dot{\bar{\sigma}}_{m}+\frac{1}{3} \dot{\sigma}_{k k}\right)
$$

\section{ここで $\sigma_{k k}$ は垂直态力の和である.}

これまで広く用いられて来た PSCN のみを考えたボ イド発生モデルは仮に母材中の介在物に大きな静水圧 が作用しても相当塑性ひずみには影響が無いために母 材と介在物が剥離を起こさないためボイド発生モデル としては不十分な面のあるモデルと考えられる. そこ で本研究ではPSCN と SCN の両者の影響を考慮する必 要性があると考え式（6）のボイド発生モデルを用い るものとした.

$$
\dot{f}_{\text {nucleation }}=A \dot{\bar{\varepsilon}}_{m}^{p}+B\left(\dot{\bar{\sigma}}_{m}+\frac{1}{3} \dot{\sigma}_{k k}\right)
$$

式 (6) にはボイドの発生頻度を決めるパラメータ $A, B$ が含まれている. ボイドの発生モデルに関するパラメ 一夕の決定法は従来の研究では実験と FEM 解析で得 られた荷重変位曲線の差が出来るだけ小さくなるよう なパラメータを用いるといら方法が主流(16)であった.

しかし，この方法では実験で得られた荷重変位曲線と 一致するパラメータの組み合わせがいくつも存在して しまう場合があり,複数のパラメータを決めるには条件 が不足している. そこで本研究ではさらにパラメータ を絞り込む条件として丸棒引張り問題におけるき裂進 展挙動を考慮した. 以下に本研究で行った各パラメー 夕の同定法を示す．まず始めに丸棒単軸引張りを実験 と FEM 解析で行い両者の荷重変位曲線が一致するよ うなパラメータを見つける. 図 11 に丸棒引張り試験 片, 図 12 に FEM 解析モデルを示す. 解析モデルは図 11 の平滑部のみについて作成し, 対称性を考慮して 全体の $1 / 8$ モデルとした. また図 12 （b）のよう な正弦曲線形状の初期不正量を式 (7)により与えた.

$$
d x=0.005 L \cos \left(\frac{\pi}{H} y\right)
$$

ただしここでL=7mm、H=3 0mm である.

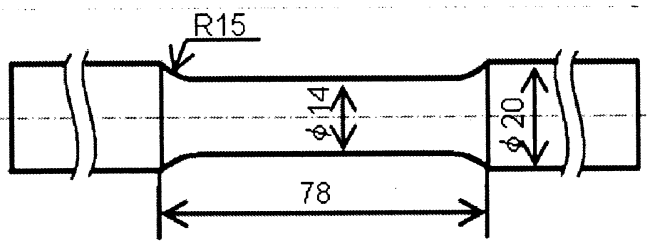

Fig. 11 Specimen of tensile test

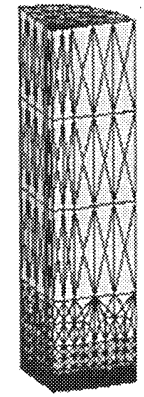

(a) Whole mesh

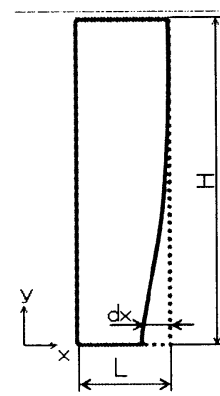

(b) Initial imperfection

Fig. 12 Mesh of tensile test

Table 4 Combination of $\mathrm{A}$ and $\mathrm{B}$

\begin{tabular}{|c|c|c|c|}
\hline & Case I & Case II & Case III \\
\hline$A$ & $1.0 \times 10^{-1}$ & $5.0 \times 10^{-2}$ & $1.0 \times 10^{-2}$ \\
\hline$B$ & $1.0 \times 10^{-6}$ & $5.0 \times 10^{-6}$ & $1.0 \times 10^{-5}$ \\
\hline
\end{tabular}


図 13 に丸棒単軸引張りにより得られた荷重変位曲線 を示す. 図 13 のように実験から得られた荷重変位曲 線の荷重負荷が減少する点すなわちくびれの開始点ま で一致するような $A, B$ 組み合わせとして表 4 に示 すような 3 組が得られた. 図 14 (a) に示寸様に実験 では材料内部で平坦破壊領域，材料表面近傍で傾斜破 壊領域が現れる. これは丸棒単軸引張り試験における 延性材料の典型的な破壊形式でありカップアンドコー ン破壊と呼ばれている，そこで，表 4 に示す各パラメ

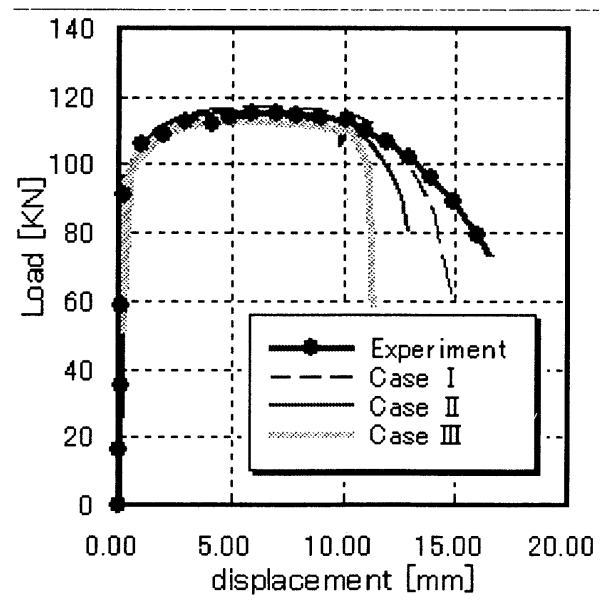

Fig. 13 Load-displacement curve

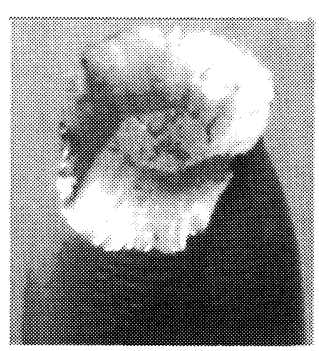

(a) Experiment

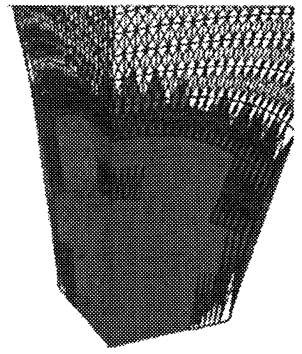

(b) Case I

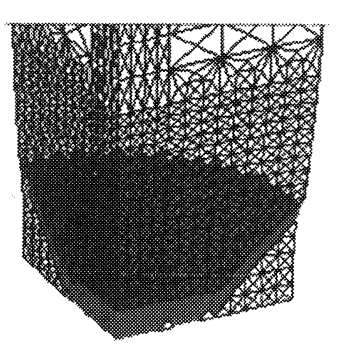

(c) Case II

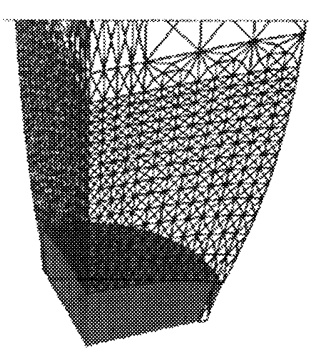

(d) Case III
Fig. 14 Cup and Cone fracture
一タを用いてき裂進展解析シミュレーションを行い, カップアンドコーン型の破壊を上手く表現できるもの を A533B 鋼のパラメータとするものとした. 図 14 (b),(c),(d)は表 4 に示寸各パラメータを用いて丸棒引張 り問題のき裂進展解析を行った結果である. 黒い要素 は破壊領域を示す. 解析の結果, Case II のパラメータ を用いると, 図 14 (c)のようにカップアンドコーン破 壊の形状を定性的に再現する事ができたが，その他の パラメータでは図 14 (b) ,(d)の様にカップアンドコ 一ン破壊を再現する事ができなかった，以上から本研 究では延性破壊を定性的に表現し得るパラメータの組 み合わせとして Case II のものを用いることにした.

このパラメータを用いて再び二次元解析を行った.

図 9 のき裂先端部における応力三軸度分布を図 15 に, 相当塑性ひずみ分布を図 16 に示す，ただし左図は $\mathrm{PSCN}$ のみを用いた結果であり,右図はPSCN と SCN の 両方を用いたものである. 応力三軸度とは静水圧を相 当応力で割ったもので定義されている.

図 15 , 図 16 を見ると PSCN のみを用いたモデルで は応力三軸度の高い領域よりも相当塑性ひずみの高い 領域に向かってき裂が進展している.これはボイドの 発生が式（3）で示すような相当塑性ひずみに依存し ているためだと考えられる. 一方, $\mathrm{PSCN}$ と SCN の両方 のボイド発生モデルを用いた場合では応力三軸度の高

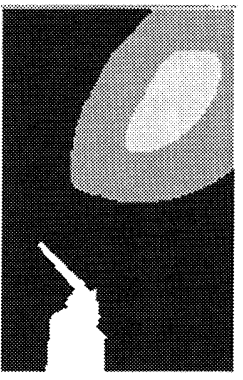

(a) PSCN

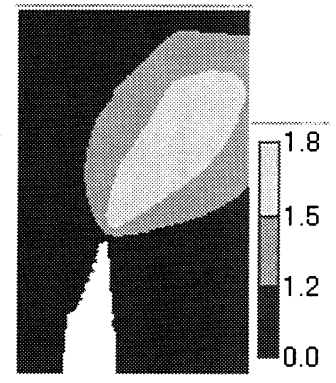

(b) $\mathrm{PSCN}+\mathrm{SCN}$
Fig. 15 Stress triaxiality

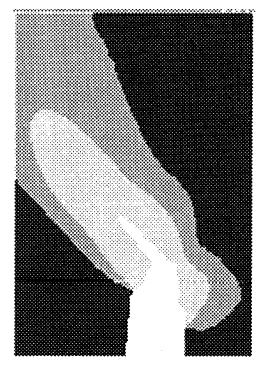

(a) PSCN

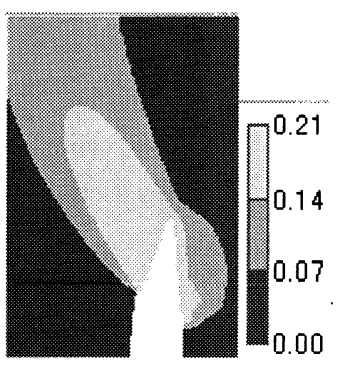

(b) $\mathrm{PSCN}+\mathrm{SCN}$
Fig. 16 Equivalent plastic strain 
い領域に向かってき裂が進展している. すなわち応力 三軸度の高い領域では静水圧成分が比較的大きいので 式 (6) の静水圧項がボイドの発生に大きく関与し,図 のような方向にき裂が進展したものと考えられる. ま た PSCN のみの場合と比較するとき裂進展方向が大き く異なり,き裂進展角度が正值を取る点で実験結果と定 性的に一致するものとなった.

$4 \cdot 3$ 三次元解析 そこでこれらのパラメータと ボイド発生モデルを用いて,シャリップ破壊領域も考慮 した混合モード延性破壊現象を調べるために三次元解 析を行った. 図 17 に 3 点曲げ解析モデルを示す. 混 合モード比は 0.25 , 板厚方向の対称性を考慮して $1 / 2$ モデルを作成した. また, 図18（a）中の点線 で示す疲労予き裂先端の形状を実測して FEM 解析モ デルのき裂先端形状を作成した.

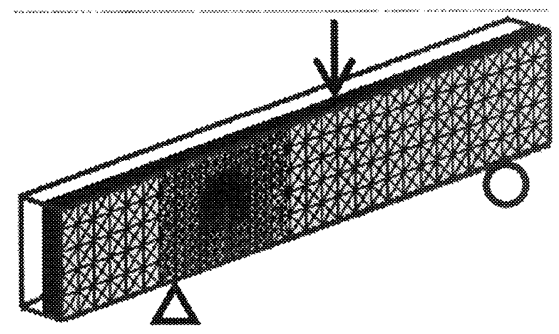

Figl.17 FEM mesh model $\quad\left(\mathrm{K}_{\mathrm{II}} / \mathrm{K}_{\mathrm{I}}=0.25\right)$

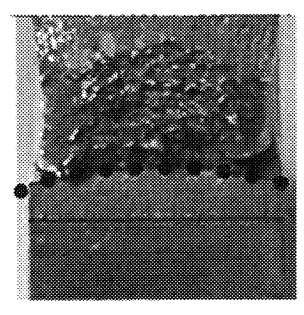

(a) Experiment

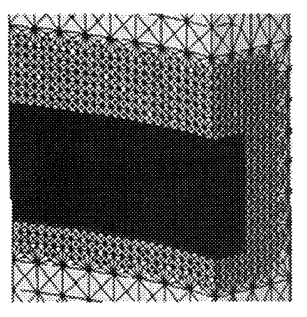

(b)FEM model
Fig. 18 Shape of pre-crack tip

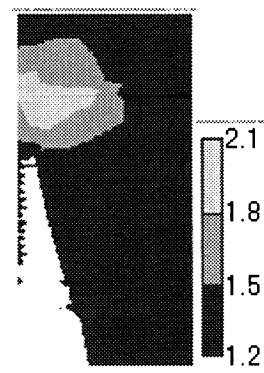

(a) Mode I $\left(\mathrm{K}_{\mathrm{II}} / \mathrm{K}_{\mathrm{I}}=0.0\right)$

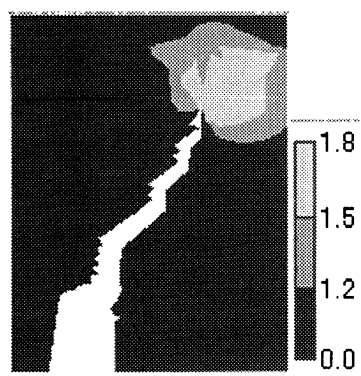

(b) $\mathrm{K}_{\mathrm{II}} / \mathrm{K}_{\mathrm{I}}=0.25$
Fig. 19 Stress triaxiality in mid-plane
図 19 に板厚中央面における応力三軸度の分布とき 裂進展の様相を示す，混合モードモデルの場合，予き 裂面からき裂進展方向が正の方向にき裂が進展してい る. これは図 5 に示した実験結果と同じ傾向になって いる. また応力三軸度はMode I モデルよりも混合モー ドモデルの方がき裂先端近傍で低い值になっている. 過去の多くの研究(17) (18) 加応力三軸度の高い領域に き裂が進展する時，大きなディンプルが形成される傾 向が知られている. すなわち図 19 の結果は混合モー ドモデルの方がディンプルが成長しにくい環境下にお かれていることを意味しており, 図8の実験結果と定 性的に一致する結果となっている.

図 20 は試験片表面での応力三軸度とき裂進展の様 子である. 試験片表面では混合モードモデルの場合予 き裂面から負の方向にき裂が進展している.この事は 図6のき裂進展画像と定性的に一致している. また板 厚表面では全体的に低い忘力三軸度分布となっており， ディンプル径の小さい破面が形成される事が推測でき る. これは自由表面では表面に垂直な応力成分が $\mathrm{O}$ なるために静水圧が低下し, その結果応力三軸度が低 下寸る事が理由である.

図 21 には板厚表面における相当塑性ひずみの分布 を示す，板厚表面では相当塑性ひずみの大きい領域に 向かってき裂が進展している様子が見られる. 式 (6) に示した様に相当塑性ひずみもボイドの発生に大きく 関与するため, 図 21 から板厚表面ではボイドが比較

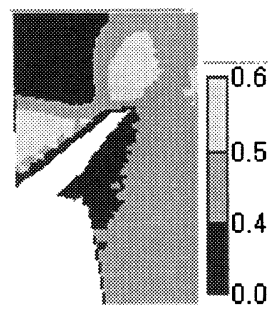

(a) Mode I $\left(\mathrm{K}_{\mathrm{II}} / \mathrm{K}_{\mathrm{I}}=0.0\right)$

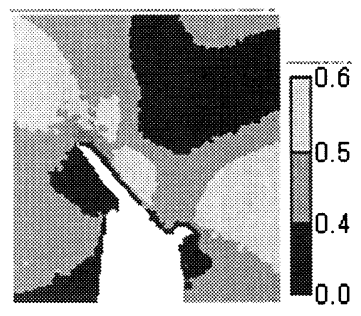

(b) $\mathrm{K}_{\mathrm{II}} / \mathrm{K}_{\mathrm{I}}=0.25$
Fig. 20 Stress triaxiality in free surface

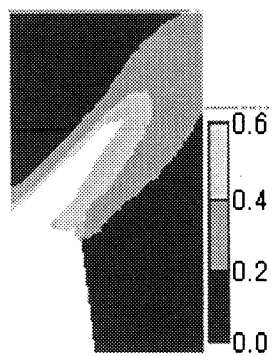

(a) Mode I $\left(\mathrm{K}_{\mathrm{II}} / \mathrm{K}_{\mathrm{I}}=0.0\right)$

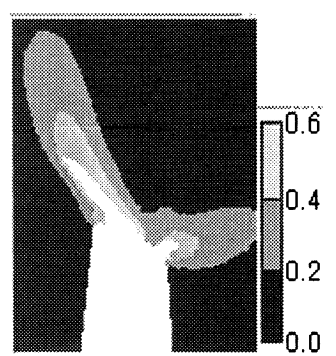

(b) $\mathrm{K}_{\mathrm{II}} / \mathrm{K}_{\mathrm{I}}=0.25$
Fig.21 Equivalent plastic strain in free surface 
的発生しやすい環境下でき裂が進展しているものと考 えられる. 以上の考察から板厚表面付近の破面状態を 考えると,ここではボイドの発生が著しいものの応力三 軸度が低いためボイドは成長しにくく,結果として小さ なディンプルが密集した破面が形成されるものと推測 する事ができ, 図6に示した自由表面近傍の破面と比 較するとその傾向が良く現れている様子が見られる.

さらに破壊した要素のうち,ボイドの発生項の総和に対 してPSCN の項と SCN の項がどれほどの割合を占めて いるのか調べた. 図 22 はその割合を予き裂先端から 0. $5 \mathrm{~mm}$ の距離にある破壊要素について調べたもの である. 図 22 の横軸の $\mathrm{y}$ は板厚表面からの深さを示 しBは板厚を示す.すなわち横軸が 0 の時に板厚表面 を示し 1 の時に板厚中央面を示す. 図 22 から板厚中 央では SCN によるボイドの発生が支配的であり,また 板厚表面近傍では PSCN によるボイドの発生が支配的 であることが分かる.これは図 19 から図 21 に示さ れたような,試験片中央部と表面部での応力三軸度と相 当塑性ひずみの分布の違いに起因するものであり, 実験 で見られたボイド寸法などの違いを定性的に説明する ものとなっている.

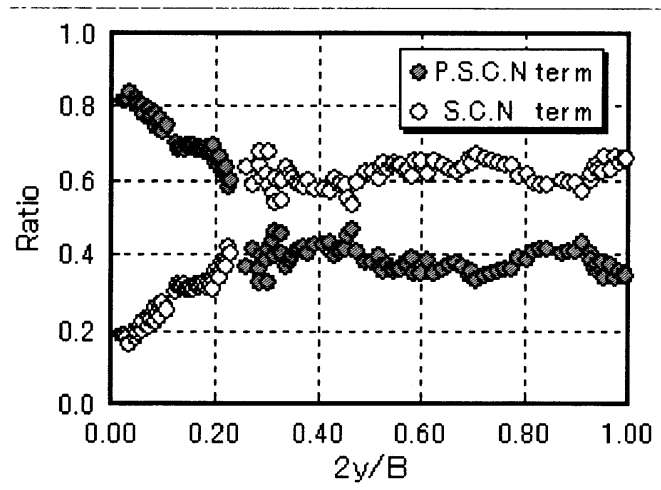

Fig. 22 Component of void nucleation $\left(\mathrm{K}_{\mathrm{II}} / \mathrm{K}_{\mathrm{l}}=0.25\right)$

\section{5. 結言}

(1)モード I およびモード II の混合モード下での延性破 壊試験を行い、延性き裂進展方向およびディンプル 径等に及ぼす混合モード比の影響を実験的に調べた. 混合モード試験片では板厚内部と板厚表面でき裂進 展方向の違いが明瞭に現れた.

(2)Gurson の構成式を用いた三次元 FEM 解析により延 性破壊シミュレーションを行った。ボイド率の発生 モデルとしてPSCN モデルと SCN モデルの両方を考 慮したボイドの発生モデルを用いることにより, 板
厚内部と表面でのき裂進展方向について実験と定性 的に一致する結果が得られた.

(3)また応力三軸度の大きさやボイドの発生項の板厚方 向分布より、実験で得られたディンプル径の板厚内 部と表面での変化、また混合モード比の影響などを 定性的によく説明できることが分かった.

\section{文献}

(1) F.Erdogan, G.C.Sih, On the crack extension in plates under plane loading and transverse shear, ASME Journal of Basic Engineering,Vol.85(1963), pp.519-527

(2)J.R.Yates, Fatigue threshold under mixed-mode(I+III) loading, International Journal of Fatigue, Vol.13, no.5(1991), pp.383-388

(3)L.P.Pook, The fatigue crack direction and threshold behavior of mild steel under mixed mode I and III loading, International Journal of Fatigue, vol.7, No.1(1985), pp.21-30

(4) K.Kishimoto, S.Aoki, N.Takeuchi, An elastic-plastic finite element analysis of a blunting interface crack with micro void damage, International Journal of Fracture, Vol.55(1992), pp.363-374

(5)K.Tohgo and H.Ishii,Elastic-plastic fracture toughness test under mixed mode I-II loading, Engineer Fracture Mechanics, Vol.41, No.4(1992), pp.529-540

(6) D.L.Holt, P.S.Khorand and M.O.Lai, The relation between the fracture toughness of plates and the thickness of the shear lips, Engineering Fracture Mechanics, Vol.6, No.2 (1974), pp.307-313.

(7) R.A.H.Edwards and J.Zuidema, Factors controlling the width of shear lips in fatigue crack growth, Engineering Fracture Mechanics, Vol.22, No.5(1985), pp.751-758.

(8)The Japan Society of Mechanical Engineers ed, $J_{I C}$ Testing Standard ( in Japanese ), ( 1992 ), pp.37-38, Maruzen Ltd.

(9)A.L.Gurson, Continuum Theory of Ductile Rapture by Void Nucleation and Growth, Journal of Engineering Materials and Technology, Vol.99, No. 1(1997),pp.2-15

(10)V.Tvergaard, On localization in ductile materials containing spherical voids, International Journal of Fracture, Vol.18, No.4(1982), pp.237-252

(11)A.K.Ghosal and R.Narasimhan, Numerical simulations of hole growth and ductile fracture initiation under mixed-mode loading, International Journal of Fracture, Vol.77(1996), pp.281-304

(12) C.Betegon, C.Rodriguez and F.J.Belzunce, Analysis and modelisation of short crack growth by ductile fracture micromechanisms, Fatigue \& fracture of engineering materials and structures, Vol.20, No.5(1997), pp.633-644

(13)C.C.Chu, A.Needleman, Void nucleation effects in biaxially stretched sheets, Journal of Engineering Materials and Technology, Vol.102(1980), pp. 249-256

(14) M.Kikuchi and S.Sannoumaru, Study on the ductile fracture including the shear-lip fracture, The Japan Society of Mechanical Engineers A, Vol.73(2007), pp.934-941

(15) A.S.Argon, J.IM, and R.Safoglu, Cavity formation from inclusions in ductile fracture, Mettallurgical Transactions A, Vol.6(1975), pp.825-837

(16) Y,Yoshida, Deformation analysis of shearing process using rigid plastic FEM employing fracture phenomenon, Journal of JSTP, Vol.44, No.510(2003), 
pp735-739

(17) M.Kikuchi and T.Ishihara, Study on Thickness Effect of Three Point Bend Specimen, The Japan Society of Mechanical Engineers A, Vol.70(2004),pp.1778-1784

(18) A.Otsuka, T.Miyata, T.Sakurai and H.Iida,Effect of stress triaxiality on ductile fracture, Journal of the Society of Materials Science, Vol.34, No.381(1984), pp.622-626 